DOI https://doi.org/10.30525/978-9934-588-90-7-63

\title{
ОСОБЛИВОСТІ ПЕРЕДАЧІ ІТАЛІЙСЬКИХ ДІАЛЕКТИЗМІВ ПРИ ПЕРЕКЛАДІ
}

\author{
Расвська I. B. \\ кандидат філологічних наук, \\ доиент кафедри теорії та практики перекладу \\ Одеський національний університет імені I. І. Мечникова \\ м. Одеса, Україна
}

Відтворення діалектизмів створює певні труднощі при перекладі художнього тексту, особливо якщо це стосується діалекту, який не має відповідника в мові перекладу. Перекладаючи текст того чи того художнього твору, зміст якого наповнений етнокультурною інформацією, фахівець змушений буде вибирати між відтворенням специфіки, національного колориту (з урахуванням того, що існує небезпека перевантажити реципієнта цільової мови та викликати багато непорозумінь) чи опусканням насиченої, прихованої конотацією національно маркованої лексики, що відповідно спричинить втрату стилю твору вихідної мови та одомашнення результатів перекладу. Лише інколи вдається поєднати два фактично протилежні завдання (наприклад, застосування комбінованої реномінації).

Серед перекладацьких труднощів щодо відтворення діалекту варто виділити такі: 1) відсутність у мові перекладу аналогічних мовних одиниць; слушною, із цього приводу $є$ думка російського науковця В. Виноградова, який зазначав, що «лексика конкретної мови в діалектному плані зонально маркована лише в ареалі поширеності цієї мови і не може мати еквівалентів 3 відповідним маркуванням в іншій мові» [1, 183], відповідно дуже важко відшукати еквівалент діалекту мови оригіналу зі схожим значенням і формою в мові перекладу; 2) необхідність відтворення історичного i національного колориту діалектного мовлення, не прийнятого в межах перекладного тексту. Труднощі перекладу аномалій діалектного мовлення науковці пропонують долати за допомогою різноманітних стратегій перекладу

Класик українського перекладознавства Р.П. Зорівчак констатує, що якщо весь текст написаний діалектом, то його здебільшого перекладають літературною мовою. Водночас, вчена не схвалює такого способу перекладу, вважаючи, що хоч для деяких авторів таких текстів діалект і 
був рідною мовою, саме він допомагав їм досягти більшої «яскравості зображення», ніж це можливо засобами літературної мови [5, с. 144].

Н.А. Фененко також вказує на часте використання компенсації при перекладі діалектизмів; іншим можливим способом перекладу, на іiі думку, є використання соціальних діалектів у мові перекладу $[13$, c. 125-126]. Таким чином, ми погоджуємося 3 авторами двох попередніх цитат про те, що переклад діалектизмів становить проблему для перекладача, при вирішенні якої доводиться або замінювати діалектизми лексемами, що належать до літературної мови, або використовувати діалекти мови перекладу. Особливості використання діалектів у мові перекладу докладно розглядає А.С. Галас. Так, наводячи приклади способів перекладу діалектизмів - компіляції діалектів, використання псевдо-діалекту, паралельного діалекту, локалізації, стандартизації, - вона також пропонує спосіб «компенсації просторіччям» [3, с. 191]. Іншими словами, перекладач художнього тексту має великий вибір стратегій щодо вирішення завдання перекладу діалектизмів, що узалежнює адекватність перекладу від цього вибору в більшій мірі. Ще одним способом передачі діалектизмів $\epsilon$ транслітерація с подальшим коментарем.

Сучасні перекладознавці і перекладачі здебільшого погоджуються на тому, що для відтворення діалектизмів необхідно використовувати просторіччя. І. Лєвий зазначає, що «...не обов'язково, щоб у народному мовленні кожному розмовному звороту оригіналу відповідало просторіччя в перекладі: воно може бути використаним в іншому місці за умови, щоб загальне враження від мовленнєвої характеристики збереглося незмінним» [7, с. 148]. Саме прийом компенсації часто дозволяє перекладачу досягти не часткової, формальної, а загальної функціональної та стилістичної відповідності: йдеться про переклад окремих елементів тексту з урахуванням комплексу змісту і мовної форми матеріалу, що перекладається. На думку О. Медвідь, адекватним вважається той переклад, при якому відповідники у цільовій мові побудовані на тих самих прагматичних компонентах значення, що й одиниці англійського діалектного мовлення [8]. Таким чином, стратегією перекладу діалектизмів $\epsilon$ передача їх семантичних, емоційноекспресивних та стилістичних рис.

Італійські письменники дуже часто пишуть свої твори 3 використанням діалектизмів, чи навіть цілі твори написані різними діалектами. Одним $з$ таких авторів $є$ відомий Андреа Каммільєрі. Розглянемо деякі 3 прикладів використання їм діалектизмів на стратегій перекладача при їх передачі на іншу мову. Для аналізу був обраний роман «Собака 3 
теракоти», який побачив світ у 1996 році. У цьому дослідженні ми аналізували способи відтворення діалектизмів у російськомовному перекладі А. Кондюріної, тому що цей роман ще не перекладений на українську мову.

Використання діалекту у Камільєрі виконує різні функції: насамперед, існує потреба більш конкретно визначити місця дій, оскільки Камільєрі говорить не про загальнолюдські події, а про події, що відбувались у конкретному місті та у конкретний час. Ця функція більш широкого захоплення у реальність добре відома і використовується багатьма сучасними письменниками. Інша функція - змусити читачів відчути певні комічні, жартівливі обставини, які часто призводять до іронії. Камілльєрі розважає читача, але перш за все викликає роздуми, засуджує таку історичну реальність, як сицилійська мафія, сповнена страждань i несправедливості. Діалект також використовується у надзвичайно драматичних обставинах. Автор використовує діалектизми у прямій мові персонажів, будуючи фразу цілком діалектом чи використовує говірки та крилаті вирази сицілійським діалектом:

Peju de li delinquenti! Peju de li assassini ci hanno trattato quei figli di lorda buttana! E chi si credono dessiri? Strunzi!...Cosi di pazzi! Cosi di pazzi $[15$, c. 49$]$.

Ciccino, ma cu e' a chistura? [15, c. 112].

Rapriti pipiti e chiuditi popiti [15, c. 92].

Крім того, часто автор міксує діалект з італійською мовою стандарт:

Dei morti se ne fotteva altamente, poteva dormirci 'nzemmula, fingere di spartirci il pane o di giocarci a tressette e briscola, non gli facevano nessuna impressione, ma quelli che stavano per morire invece gli provocavano la sudarella, le mani principiavano a tremargli, si sentiva agghiacciare tutto, un pirtuso gli si scavava dintra lo stomaco. [15, c. 75].

Eh no, duttureddru, non e' la stessa cosa, mi meraviglio di lei che sapi leggiri e scriviri, le parole non sono uguali. Io mi faccio arrestare, non mi costituisco. Si pigliassi la giacchetta che ne parliamo dintra, io intanto rapro la porta $[15$, c. 20$]$.

Також один з героїв роману говорить іншим італійським діалектом (міста Генуя), відмінним від діалекту місцевості, де розгортаються події, які не зрозумілий мешканцями Сицілії. Сам автор пояснює це тим фактом, що завдяки цьому він розкриває складну особистість героя.

Висновки. У ході аналізу перекладу роману було встановлено, що найчастіше перекладачка вдається до використання літературного еквіваленту та використання просторіччя. 


\section{Література:}

1. Ахманова О.С. Словарь лингвистических терминов. - Изд. 4-е, стер. М. : КомКнига, 2007. 570 с.

2. Виноградов В. С. Введение в переводоведение (общие и лексические вопросы). Москва : РАО, 2001. 224 с.

3. Галас А.С. Соціальна зумовленість розвитку перекладацьких стратегій // Мова і суспільство, 2010. Вип. 1. С. 189-198.

4. Дроздовський Д. Переклад у XXI столітті: місія нездійсненна? ЛітАкцент : 2016.

5. Зорівчак Р.П. Реалія i переклад (на матеріалі англомовних перекладів української прози). Львів : Вид-во при Львів. ун-ті, 1989. 216 с.

6. Ковтун О. В. Діалектна лексика у сучасній українській прозі в аспекті перекладу. Науковий вісник Міжнародного гуманітарного університету. Серія «Філологія». 2017. № 28. С. 184-188.

7. Левый И. Искусство перевода.- М., 1974. - 152 с. 2. Лоуренс Д.Г. Коханець леді Чатерлей / Пер. С. Павличко - Київ: Основи, 1998. 461 с.

8. Медвідь О. Проблема використання діалектизмів і просторіччя в українському художньому перекладу // Другий Міжнародний конгрес україністів. Доповіді і повідомлення (Львів, 22-28 серпня 1993 р.). Львів, 1993. С. 272-277.

9. Павличко Д. Безодня, куди страшно заглядати. Літературна Україна. 2005. № 2. С. 6.

10. Пономарів О. Д. Стилістика сучасної української мови. Київ : Знання, 1993. $248 \mathrm{c.}$

11. Селіванова О.О. Лінгвістична енциклопедія. Полтава : Довкілля, $2011.844 \mathrm{c}$.

12. Струк I. В. Стратегії відтворення аномалій діалектного мовлення в перекладі (на матеріалі творів Марка Твена та їхніх перекладів українською та російською мовами). Гуманітарна освіта в технічних вищих навчальних закладах. 2014. № 30. С. 83-97.

13. Фененко Н.А. Язык реалий и реалии языка. Воронеж. межрегиональный ин-т общественных наук, Воронежский гос. ун-т. Воронеж, 2001. $140 \mathrm{c}$.

14. Britain D., Trudgill P. New Dialect Formation And ContactInduced Reallocation: Three Case Studies From The English Fens 2005. Vol. 5. Issue 1. P. 183-209.

\section{Ілюстративний матеріал:}

15. Andrea Camilleri. Il cane di terracotta. Palermo: Sallerio Editore Palermo:1996. 288 p.

16. Андреа Каммилери. Собака из терракоты. Изд. Иностранка, 2005. $336 \mathrm{c}$. 